\title{
Effect of Incidence Angle on Capacitance of Vertical Parallel Silicon Solar Cell under Modulation Frequency
}

\author{
Gökhan ŞAHİN ${ }^{1}$
}

\begin{abstract}
In this work, the modeling for the capacitance of a vertical parallel silicon solar cell has been carried out with an analytical approach. A theory on the determination of the diffusion coefficient of the excess minority carriers of a silicon solar cell is presented. Based on the continuity equation, excess minority carrier's density, photocurrent density and photovoltage have been determined. Also, this study allows us to determine the influences of incidence angles on the photocurrent density, the photovoltage and the diffusion capacitance (open and short circuit). The objective of this work is to show the effects of incidence angles on the solar cell capacitance with these electrical parameters.
\end{abstract}

Keywords: Diffusion capacitance, incidence angle, vertical parallel silicon solar cell

\section{Modülasyon Frekansı Altında Geliş Açısının Dikey-Paralel Silisyum Güneş Pili Kapasitansına Etkisi}

ÖZET: Bu çalışmada, analitik yaklaşımla dikey paralel silisyum güneş pili kapasitansı için modelleme yapıldı. Silisyum güneş Pilinin aşırı azınlık taşıyıcıları difüzyon katsayısının belirlenmesi ile ilgili bir teori sunuldu. Süreklilik denklemine bağlı olarak aşırı azınlık taşıyıcıların yoğunluğu, foto akım yoğunluğu ve foto gerilim belirlendi. Ayrıca, bu çalışma foto akım yoğunluğu, foto gerilim ve difüzyon kapasitansına (açık ve kısa devre) geliş açısının etkilerini belirlememize olanak sağlar. Bu çalışmanın amacı, bu elektriksel parametreler ile güneş pili kapasitansına geliş açısının etkisini göstermektir.

Anahtar Kelimeler: Difüzyon kapasitansı, dikey paralel silisyum güneş pili, geliş açısı

\footnotetext{
Igdir üniversitesi, Mühendislik Fakültesi, Elektrik Elektronik Mühendisliği, Igdir, Türkiye
}

eSorumlu yazar/Corresponding Author: Gökhan ŞAHIN, konyakayseri@hotmail.com 


\section{INTRODUCTION}

The improvement of the performances and the quality of solar cells is one concern major to which the current research turns. Thus, the basic material for manufacturing solar cells benefit ceaselessly technological progress as well on the mode of the manufacturing and the increase substrates as on the final structure of the solar cell elaborated. For that purpose, many researches are done on conventional solar cells, solar cells with back field or B.S.F (Back Surface Field) (Grove, 1967; Ricoud, 1997), monocrystalline and polycrystalline monofocal silicon solar cells, polycrystalline and monocrystalline bifacial silicon solar cell (Kocyigit, 2012, Topkaya, 2016) vertical junctions solar cells, solar cells with concentration... The purpose of this article is to do a study on a parallel vertical junction silicon solar cell under multispectral illumination in static regime. A theoretical study of the excess minority carriers in the base of the solar cell is produced through continuity equation. With help of the boundary conditions at the junction and at the middle of the base, excess minority carrier's density are studied and lead to the expression of photocurrent density and photovoltage. From, the well-known I-V characteristic of the solar cell under illumination, electrical equivalent model is established for low and high junction recombination values giving respectively ideal generator source of tension and current.

So many studies have been conducted in order to minimize this recombination and raise the conversion efficiency. Related to the operating conditions, solar cell characterization methods lead to the electrical and recombination parameters (bulk and surfaces) (Ghitani et al, 1989; Nam et al, 1992). Then solar cell is either under steady state condition (Ly et al, 2013) or under dynamic state (Mbodji et al, 2010) (i.e. transient decay and frequency)

Space charge region capacitance is expressed depending on incidence angle and junction recombination velocity.

\section{MATERIAL AND METHOD}

Figure 1 represents parallel vertical junction solar cells under monochromatic light, in one dimensional model (Ox), where the studied p-base1 interacts with the two adjacent emitters

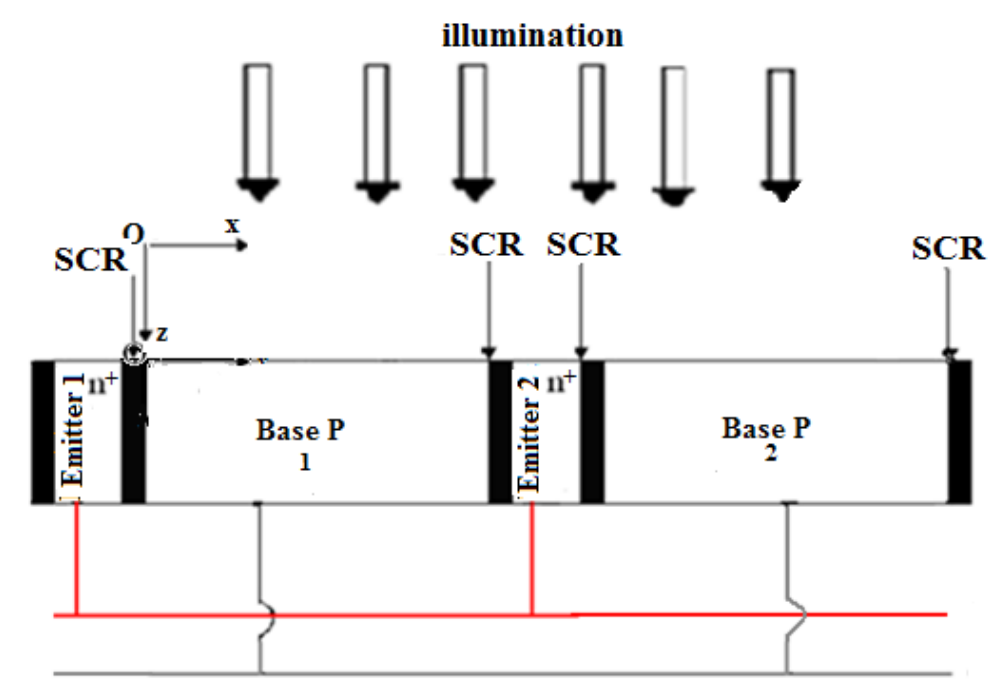

Figure 1: ๆvertical parallel junction silicon solar cells

9Given that the contribution of the base to the photocurrent is larger than that of the emitter (Samb et al, 2009; Lemrabott et al, 2012) our analysis will only be developed in the base region. Taking into account the generation, recombination and diffusion phenomena in the base, the equation governing the variation of the minority carriers density $\delta(\mathrm{x}, \mathrm{y}, \mathrm{z}, \mathrm{t})$ under modulation frequency Tis (Noriaki et al, 1987; Noriaki et al, 1988; Mandelis, 1989; Diallo et al, 2012): 


$$
D(\omega) \cdot \frac{\partial^{2} \delta(x, \theta, t)}{\partial x^{2}}-\frac{\delta(x, \theta, t)}{\tau}=-G(z, \theta, t)+\frac{\partial \delta(x, \theta, t)}{\partial t}
$$

$\mathbb{} \mathrm{D}(\omega)$ and $\tau$ are respectively, the excess minority carrier diffusion constant and lifetime (Dieng et al, 2011).

The excess minority carriers' density can be written as:

$$
\delta(x, t)=\delta(x) \exp (-j \omega t)
$$

Carrier generation rate $\mathrm{G}(\mathrm{z}, \boldsymbol{\theta}, \mathrm{t})$ is given by :

$$
G(z, \theta, \lambda, t)=g(z, \theta, \lambda) \exp (-j \omega t)
$$

Were

$$
g(z, \theta, \lambda)=\alpha(\lambda)(1-R(\lambda)) \cdot \phi(\lambda) \exp (-\alpha(\lambda) \cdot z) \cos (\theta)
$$

$\mathrm{x}$ is the base depth along $\mathrm{x}$ axis, $\omega$ is the angular frequency, $\theta$ is the incidence angle, $\mathrm{z}$ the base depth according to the vertical axis ; Sf is the junction recombination velocity and $\lambda$ the illumination wavelength. If we replace equation (2) into equation (1), the temporary part is eliminated and we obtain:

$$
\frac{\partial^{2} \delta(x)}{\partial x^{2}}-\frac{\delta(x, \theta, t)}{L(\omega)^{2}}=-\frac{g(z, \theta)}{D(\omega)}
$$

The solution of this equation is:

$$
\delta(x, \omega, \theta, z, S f, \lambda)=A \cosh \left(\frac{x}{L(\omega)}\right)+B \sinh \left(\frac{x}{L(\omega)}\right)+\frac{L(\omega)^{2}}{D(\omega)} \cdot \alpha(\lambda)(1-R(\lambda)) \cdot \phi(\lambda) \cdot \exp (\alpha(\lambda) \cdot z) \cdot \cos (\theta)
$$

\Coefficients A and B are determined through the following boundary conditions (Diallo et al, 2008).

- at the junction $(\mathrm{x}=0)$ :

$$
\left.D(\omega) \cdot \frac{\partial \delta(x, \omega, \theta)}{\partial x}\right|_{x=0}=\left.S f \cdot \delta(x, \omega, \theta)\right|_{x=0}
$$

Sf is the excess minority carrier's recombination velocity at each junction (Avraham et al, 1974).

- at the middle of the base $(x=H / 2)$ :

$$
\left.D(\omega) \cdot \frac{\partial \delta(x, \omega, \theta)}{\partial x}\right|_{x=\frac{H}{2}}=0
$$


The excess minority carriers in the base will flow to the two junctions by diffusion; the photocurrent

$$
J_{P h}=\left.2 \cdot q \cdot D(\omega) \cdot \frac{\partial \delta(x, \omega, \theta)}{\partial x}\right|_{x=0}
$$

were $\mathrm{q}$ is the elementary charge.

The expression of the density of minority carriers in excess $\delta(\mathrm{x})$ is thus a dependent function of the depth $\mathrm{x}$ in the base of the $\theta$ angle, recombination velocities at the junction Sf rear, diffusion length $\mathrm{L}$ and the diffusion coefficient $\mathrm{D}$ of the minority carriers. density is given by the following expression:

\section{RESULTS AND DISCUSSIONS}

Figure 3, by cons, the curves have a positive gradient in the immediate vicinity of the junction, which means that the minority carriers located a this level through the junction to participate á producing a photocurrent. In both cases the charge density of minority carriers increases when the incidence angle decreases.

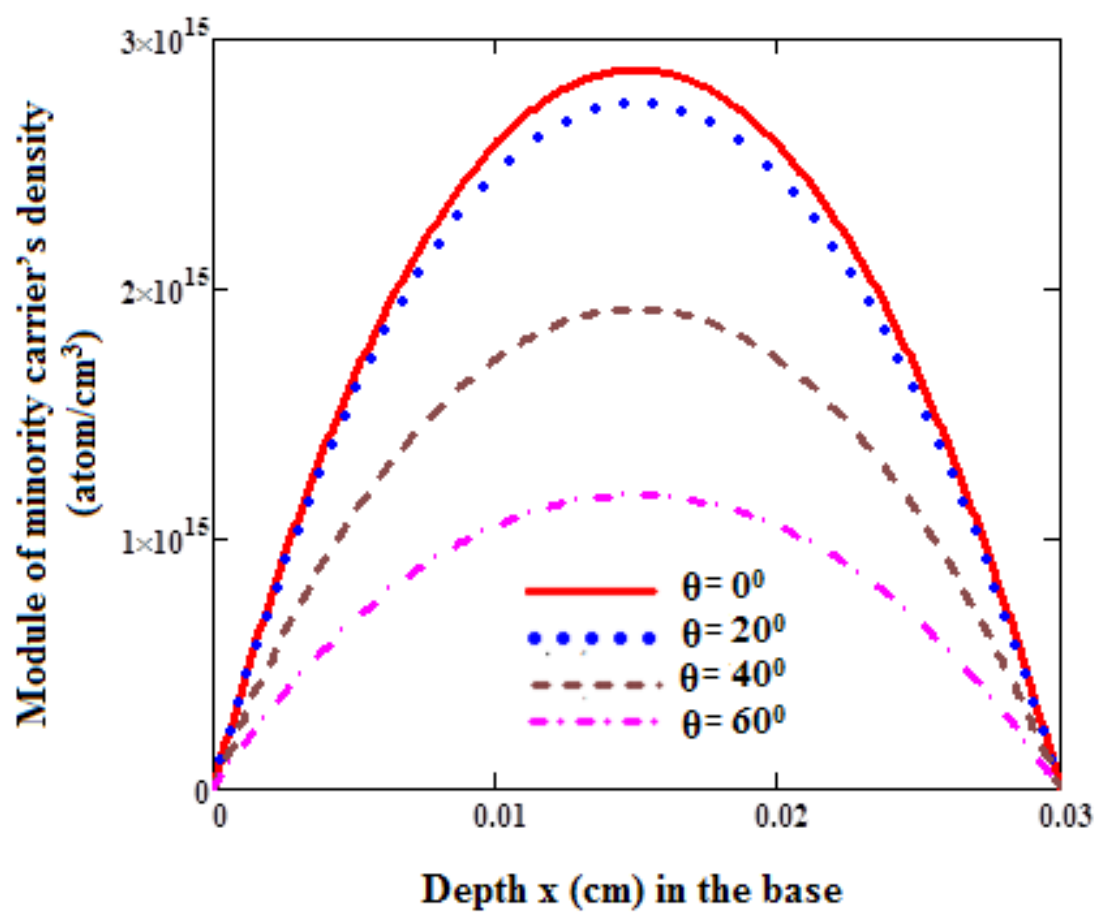

$$
\begin{gathered}
\mathrm{Sf}=3.10^{3} \mathrm{~cm} / \mathrm{s} . \\
\mathrm{H}=0.03 \mathrm{~cm} ; \quad \mathrm{L}_{\mathrm{o}}=0.02 \mathrm{~cm}, \mathrm{D}_{\mathrm{o}}=26 \mathrm{~cm}^{2} / \mathrm{s}, \mathrm{z}=0,0001 \mathrm{~cm}, \quad \lambda=0.68 \mu \mathrm{m}, \omega=10^{3} \mathrm{rad} / \mathrm{s} .
\end{gathered}
$$

Figure 2. Module of minority carrier's density versus depth $\mathrm{x}$ in the base for various incidence angles

Photovoltage: This part is devoted to the study of the influences of the angle of incidence and rate of recombination at the junction of the photovoltage.
The photovoltage is given, at the emitter / base, according to the Boltzmann relationship by expression (10): 


$$
V_{P h}=V_{T} \cdot \ln \left[1+\frac{N b}{n_{0}^{2}} \cdot \delta(0)\right]
$$

with $\mathrm{V}_{\mathrm{T}}$ the thermal voltage,

$$
V_{T}=\frac{K_{B} T}{q}
$$

$\mathrm{K}_{\mathrm{B}}$ est la constante de Boltzmann et a pour valeur $1,3806488.10^{-23} \mathrm{~J} \cdot \mathrm{K}^{-1}$

$\mathrm{T}$ is the absolute temperature in Kelvin;

$\mathrm{n}_{\mathrm{i}}$ the intrinsic carriers' density $\mathrm{cm}^{-3}$;

$\mathrm{N}_{\mathrm{b}}$ the base doping density $\mathrm{cm}^{-3}$;

Expression of the picture voltage based on the values of the incidence angle is given by the junction recombination velocity $\mathrm{Sf}$ for different relationship (12)

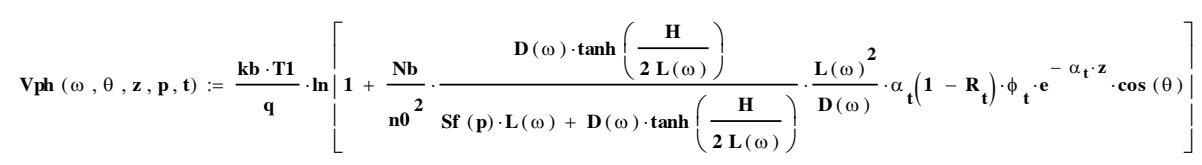

Figure 3 shows the voltage profile of the image as a the angle of incidence. The curves show that the impact of function of the recombination rate for different values of the angle of incidence on the photo-voltage is low.

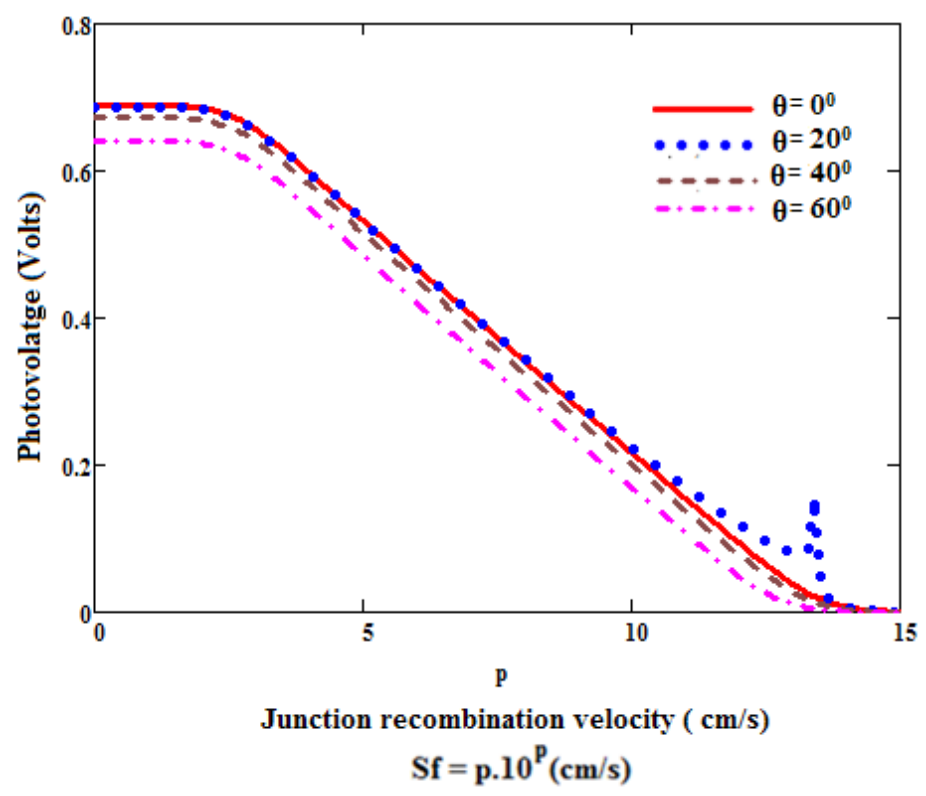

$\omega=10^{3} \mathrm{rad} / \mathrm{s}, \mathrm{H}=0.03 \mathrm{~cm}, \mathrm{~L}_{\mathrm{o}}=0.02 \mathrm{~cm}, \mathrm{Do}=26 \mathrm{~cm}^{2} / \mathrm{s}, \mathrm{z}=0.0001 \mathrm{~cm}, \lambda=0.52 \mu \mathrm{m}$

Figure 3. Module of the photo voltage versus the junction recombination velocity for various incidence angles. 
The photo voltage generally decreases with angle of incidence, but this reduction is not very significant as that of the photocurrent with the angle of incidence. With tilt, power forward will change and with it the carrier density; but as the dependence of the photovoltage to the carrier density is rather logarithmic, the influence of the angle of incidence is less noticeable on the photovoltage on the photocurrent density.

Open Circuit Photovoltage: In Figure 4, we represent the profile of the open circuit photovoltage as a function of logarithm of the modulation frequency $\omega$ for different angles of incidence:

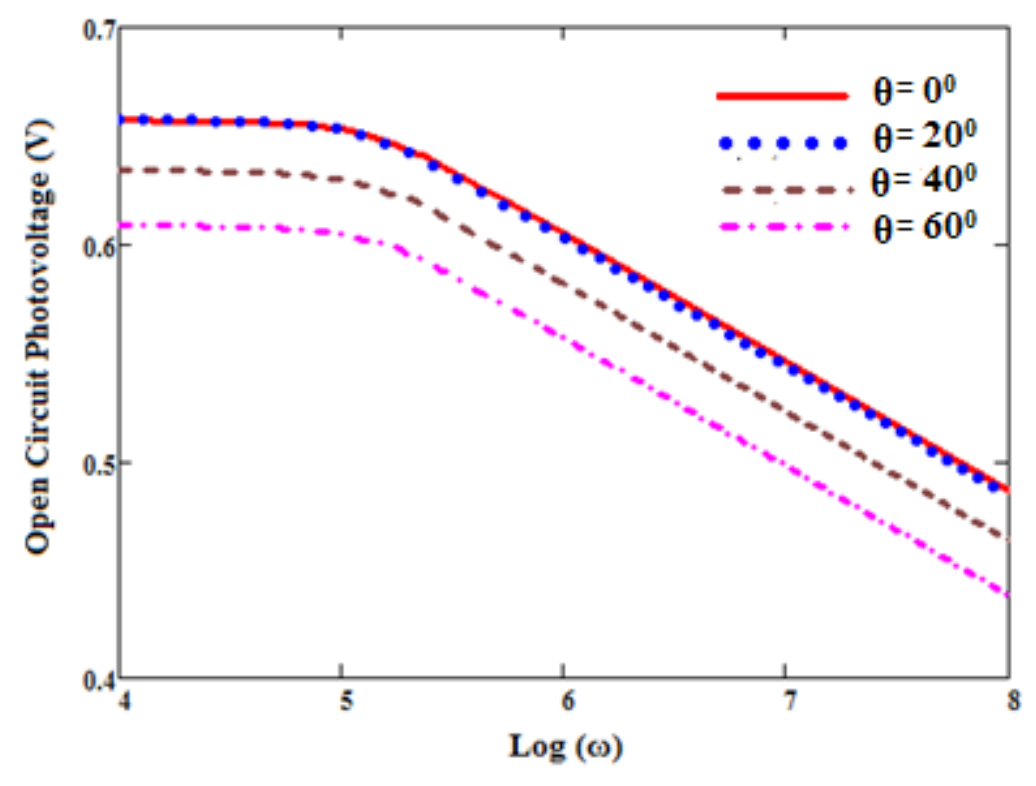

$\mathrm{Sf}=3.10^{3} \mathrm{~cm} / \mathrm{s} ; H=0,03 \mathrm{~cm} ; L_{0}=0,02 \mathrm{~cm} ; D_{0}=26 \mathrm{~cm}^{2} / \mathrm{s} ; z=0,0001 \mathrm{~cm} ; \lambda=0.52 \mu \mathrm{m}$

Figure 4. Open circuit photovoltage versus the logarithm of angular frequency for various incidence angles

This module remains substantially the same for angles $0 \leq \theta \leq 10^{\circ}$ and decreases for angles $\theta>10^{\circ}$. We also note that for the values $0 \leq \theta \leq 10^{\circ}$, the amplitude of the open circuit photovoltage hardly varies. The open circuit photovoltage is obtained when the junction recombination velocity $S f$ is very low; for an ideal cell, $\mathrm{Sf}$ should be zero $(\mathrm{Sf}=0)$ and in a real case, it would be the intrinsic junction recombination $\left(\mathrm{Sf}_{0}=0\right)$

\section{Capacitance}

When the photocell is illuminated, there is generation, diffusion and recombination of carrier's minority within the solar cell. The conduction of carriers across the junction is accompanied by a $-\mathrm{Q}$ charge storage in the base and $+Q$ in the transmitter and possibly a recombination of the minority carriers. The presence of charge opposite signs with respect to either side of the junction leads to the establishment of a variable capacitance capacitor according to the operating conditions of the solar cell. Considered as a result of the variation in load during the diffusion process within of the solar cell (Coligne, 2002; Neamen, 2003; Wenham et al, 2007; Mathieu et al, 2009; Hu, 2010; Boer, 2010; Zeghbreeck, 2011; Sane et al, 2014; Sahin et al, 2015), the solar cell capacity can put in the form:

$$
C=\frac{d Q}{d V_{p h}}
$$

Since the total charge $\mathrm{Q}$ can be rewritten as $\mathrm{Q}=\mathrm{q} \delta(\mathrm{x}=0)$, one obtains: 
$C=q \cdot \frac{d \delta(x=0)}{d V_{p h}}$

We write equation (14) in a form easier to use:

$$
C=q \cdot \frac{d \delta(x=0)}{d S f} \cdot \frac{1}{\frac{d V p h}{d S f}}
$$

Given the expression of the photo voltage (equation 9) and that of the carrier density,

we get the following equation:

$$
C=\frac{q \cdot \frac{n_{0}^{2}}{N b}}{V_{T}}+\frac{q . \delta(0)}{V_{T}}
$$

The first term in equation (16) is the intrinsic capacity $\mathrm{C}_{0}$; she depends essentially the nature of the material (that is to say, the semiconductor substrate used) to through the intrinsic concentration (ni), doping of the final material through the impurity concentration $(\mathrm{Nb})$ and the operating temperature of the junction to the Thermal photovoltage $\mathrm{V}_{\mathrm{T}}$.

As for the second term, it depends mainly on the temperature through $\left(\mathrm{V}_{\mathrm{T}}\right)$, the doping material and its nature through the coefficient $\mathrm{D}$ and the diffusion length L from the point of operation through the recombination rate at the junction $(\mathrm{Sf})$ and the dimension the solar cell through its thickness $(\mathrm{H})$.

The capacity of the solar cell is the sum of the transition ability and the ability to diffusion; depending on the mode of operation of the solar cell that is to say when the latter is direct or reverse bias, one of two capacitors predominates.

Under reverse bias, diffusion phenomena are nonexistent. The junction is characterized by two charges of opposite signs motionless; there is a capacitor whose predominant ability is called transition or capacity $\mathrm{Ct}$ barrier capacity. This capacity is directly dependent on the reverse bias voltage of the solar cell and can $300 \mathrm{pF}$ reach.

Under illumination (forward bias), the phenomenon of diffusion is dominant and it is the diffusing capacity becomes the most important. If we return to equation (16), we can rewrite it and we get:

$$
\frac{C}{C_{0}}=1+\frac{N b \cdot \delta(0)}{n_{0}^{2}}=\exp \left(\frac{V_{p h}}{V_{T}}\right)
$$


Either:

$$
\ln (C)=\ln \left(C_{0}\right)+\left(\frac{V_{p h}}{V_{T}}\right)
$$

We now present the evolution of the solar cell diffusion capacity based the operating point defined through the junction recombination velocity Sf. Figures
(5) present the solar cell capacitance versus junction recombination velocity.

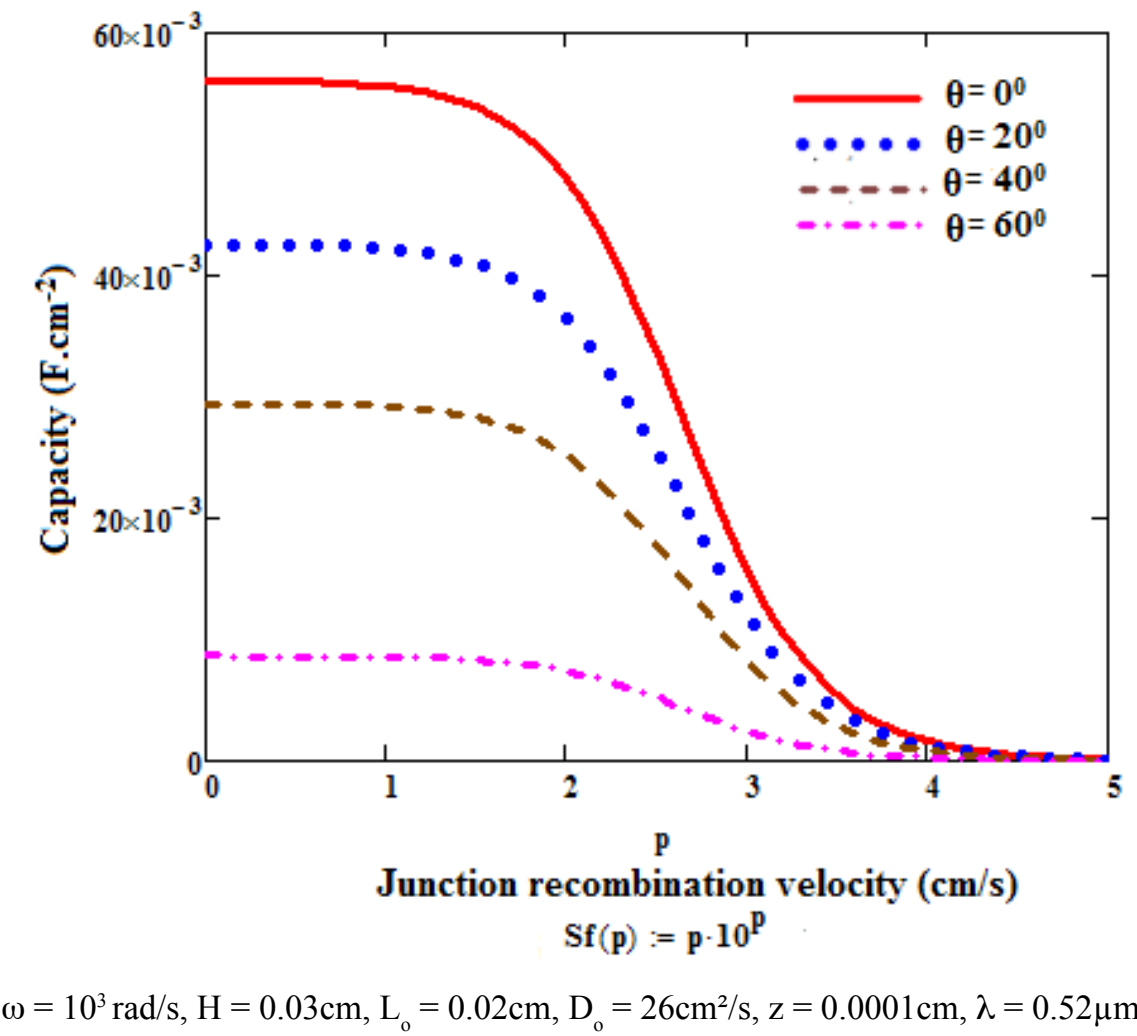

Figure 5. Module of SCR (space charge region) capacitance versus junction recombination velocity for various incident angles

The open circuit situation when the junction recombination velocity $\mathrm{Sf}$ is low, the maximum capacity is remaining practically constant: there is little mobility of the minority carriers thus substantially all of such holders are found stored in the vicinity of the junction. For $\mathrm{Sf}$ values greater than $2.10^{2} \mathrm{~cm} \cdot \mathrm{s}^{-1}$, we note a progressive decrease in the ability of the solar cell tends to a capacitance value corresponding to the short circuit condition since the base vacuum photogenerated minority carriers
For high values of Sf diffusion capacity is low reflecting a destocking of charge carriers in the immediate vicinity of the emitter-base junction.

Figure 6 shows the profile of the diffusing capacitance for low values of Sf $\left(\mathrm{Sf}<100 \mathrm{~cm} \mathrm{~s}^{-1}\right)$ corresponding an open circuit condition of the solar cell. This figure clearly shows the effect of incidence angle on the diffusion capacitance. Although this capability is seen decreases as the incidence angle increases. 


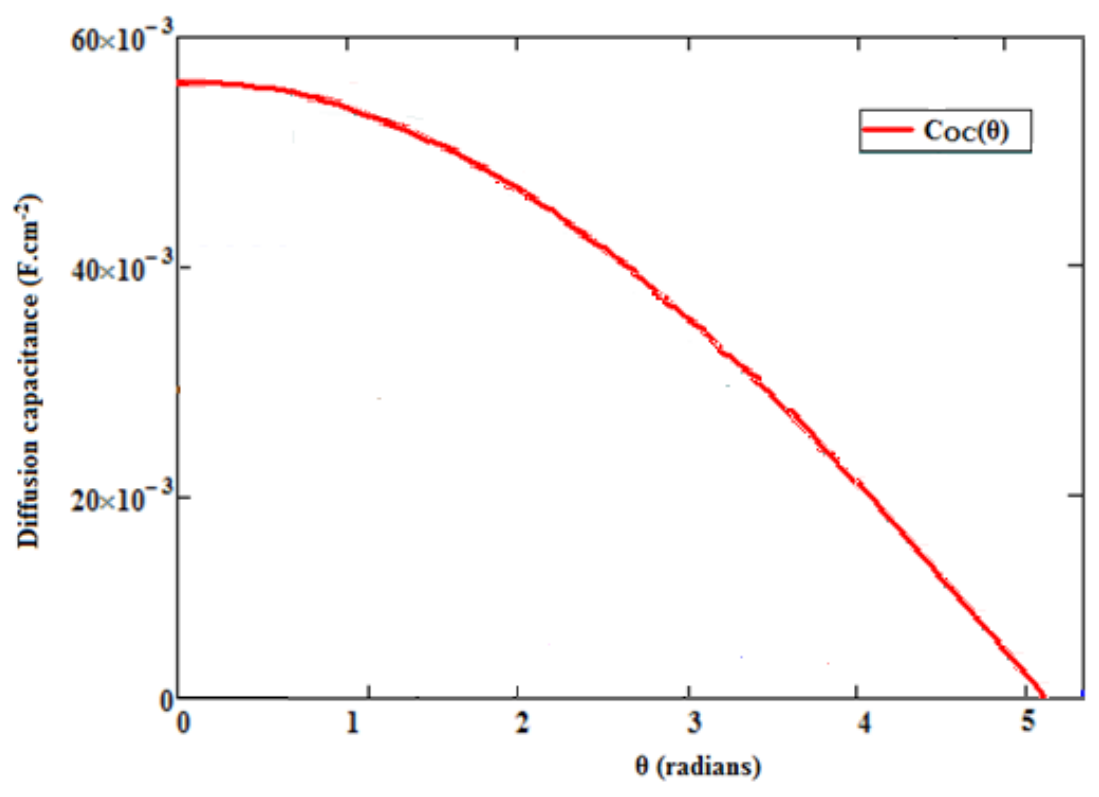

$\mathrm{Sf}=10 \mathrm{cms}^{-1}$

Figure 6. Diffusion capacity characteristics in function of incidence angle

Figure 7 shows the profile of the diffusing capacitance for high values of $\mathrm{Sf}\left(\mathrm{Sf}=10^{6} \mathrm{~cm} \mathrm{~s}^{-1}\right)$ corresponding a short-circuit situation of the solar cell. Note that this capability is significantly lower than the open circuit condition.

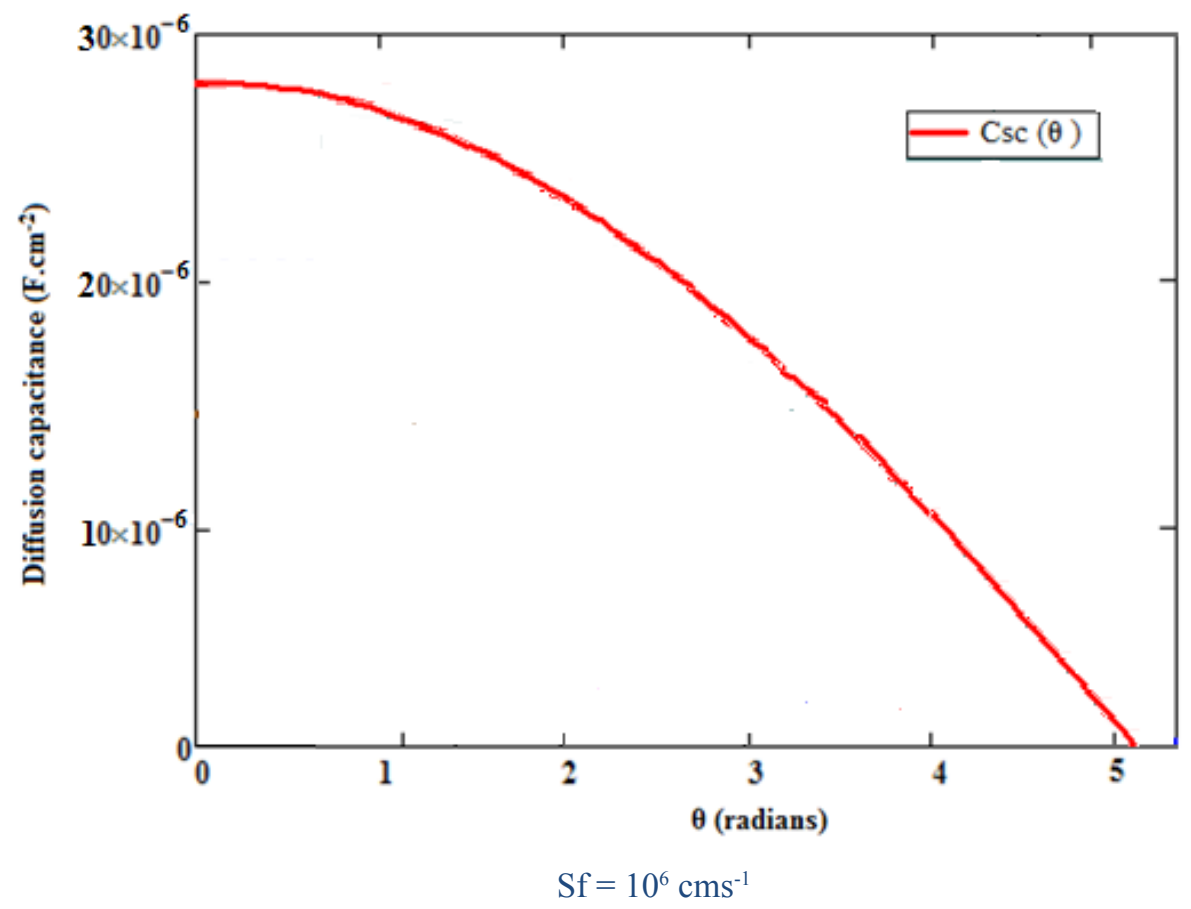

Figure 7. Diffusion capacitance characteristics in function of incidence angles 


\section{CONCLUSION}

A theoretical study has been made on a silicon solar cell under the frequency modulation for various incidence illumination angles. Electrical parameters such as the photocurrent and the photo voltage are studied and the influence of the modulation frequency and incidence angle on these parameters is presented. Excess minority carrier's density, photocurrent density, photovoltage and open-circuit photovoltage have been

\section{REFERENCES}

Avraham G, Paul S, 1974. Vertical Multijunction Solar-Cell OneDimensional Analysis; IEEE transactions on electron devices, vol. ed-21, no 6, 351-356.

Turgut G, Kocyigit A, Sonmez E, 2015. Influences of Pr and Ta doping concentration on the characteristic features of FTO thin film deposited by spray pyrolysis, Chinese Physics B, Volume: 24 Issue: 10 Article Number: 107301.

Boer KW, 2010. Introduction to space charge effects in semiconductor, third edition,Springer-Verlag, $242 \mathrm{p}$.

Colinge JP et Colinge CA, 2002. Physics of semiconductor devices, sixth edition, Kluwer Academic Publishers, 311p

Diallo HL, Dieng B, Ly I, Dione MM, Ndiaye M, Lemrabott OH, Bako ZN, Wereme A and Sissoko G, 2012. Determination of the Recombination and Electrical Parameters of Vertical Multijunction Silicon Solar Cell. Res.J. Appl. Sci. Engineering Technol. Maxwell Scientific Organization, 3(7): 602-611, ISSN: 2040-7467.

Dieng A, Zerbo I, Wade M, Maiga AS and Sissoko G, 2011. Threedimensional study of a polycrystalline silicon solar cell: the influence of the applied magnetic field on the electrical parameters, Semicond. Sci. Technol.9, 26095023.

Diallo HL, Wereme A, Maiga AS and Sissoko G, 2008. New approach of both junction and back surface recombination velocities in a 3D modelling study of a polycrystalline silicon solar cell, Eur. Phys. J. Appl. Phys. 42 203-11.

Grove AS, 1967. Physics and Technology of Semiconductor Devices, First Edition, Wiley, New York. 174 p.

Ghitani HE and Martinuzzi S, 1989. Influence of dislocations on electrical properties of large grained polycrystalline silicon cells, J. App. Phys. 66(4), 1989, pp 1717-1726.

$\mathrm{Hu}$ CC, 2010. Modern semiconductor devices for integrated circuits, fifth edition, Pearson/prentice Hall, New Jersey, 216p.

Ly I, Ndiaye M, Wade M, Thiam N, Gueye S, Sissoko G, 2013. Concept of recombination velocity Sfcc at the junction of a bifacial silicon solar cell, in steady state, initiating the shortcircuit condition, Research Journal Of Applied Sciences, Engineering And Technology 5(1): 203-208.

LemrabottZ, Bako N, Wereme A and Sissoko G, 2012. Determination of the Recombination and Electrical Parameters of Vertical Multijunction Silicon Solar Cell, Res.J. Appl. Sci. Engineering Technol. Maxwell cientific Organization, 3(7): 602-611.

Mathieu H et Fanet H, 2009. Physique des semiconducteurs et des composants électroniques, sixth edition Dunod, 158p. studied. The diffusion capacitance following two operating points (open circuit situation and short-circuit situation) versus junction recombination velocity for various incidence angles values has been studied. After than we can work the capacitance of the space charge region using the Bode and Nyquist diagrams while the solar cell remained either under open circuit or short circuit condition and illuminated with different incidence angles.

Mbodji S, Maiga AS, Dieng M, Wereme A and Sissoko G, 2010. Removal charge technique applied to a bifacial solar cell under constant magnetic field", global journal of pure and applied sciences vol 16, $\mathrm{N}^{\circ} 4,469-477$.

Mandelis A, 1989. Coupled ac photocurrent and photothermal reflectance response theoryof semiconducting p-n junctions; J. Appl. Phys. 66(11), 5572-5583.

Nam LQ, Rodot M, Nijs J, Ghannam M and Coppye J, 1992. Réponse spectrale de photopiles de haut rendement au silicium multicristallin. J. Phys. III France 2, 1992, pp 1305-1316.

Noriaki H and Munakata C, 1987. Sample thickness dependence of minority carrier Lifetimes Measured using an ac photovoltaic Method; japanese journal of applied physics vol.26,no 12,pp. 233-236.

Noriaki H, Chusuke M and Hirofimi S, 1988. Calibration of minority carrier lifetimes measured with an ac photovoltaic method; japanese journal of applied physics vol.27,no 7, pp. 1322-1326.

Neamen DA, 2003. Semiconductor physics and devices: basic principles, Third edition, McGraw-Hill, 234p.

Topkaya R ,.Güngüneş H, Eryiğit Ş, Sagar E.Shirsath A.Yıldız,. Baykal A, 2016. Effect of bimetallic (NiandCo) substitution on magnetic properties of $\mathrm{MnFe} 2 \mathrm{O} 4$ nano particles, doi:10.1016/j.ceramint.2016.05.177

Ricaud A, 1997. Photopiles Solaires, Physique des photopiles. First Edition. Lausanne, 148-155p.

Samb ML, Dieng M, Mbodji S, Mbow B, Thiam N, Barro FI, Sissoko G, 2009. Recombination parameters measurement of silicon solar cell under constant white bias light, Proceedings of the 24th European photovoltaic solar energy conference and exhibition, Hamburg, Germany (sept), $469-$ 472 .

Sane M, Sahin G, Barro FI, Maiga AS, 2014.Incidence angle and spectral effects on vertical junction silicon solar cell capacitance, Turk J Phys 38: 221 - 227.

Sahin G, Moustapha D, Mohamed AOEM, Moussa I N, Amary T, Grégoire S, 2015. Capacitance of Vertical Parallel Junction Silicon Solar Cell under Monochromatic Modulated Illumination, Journal of Applied Mathematics and Physics, 3: 1536-1543.

Wenham S R, Green MA, Watt ME et Corkish R, 2007. Applied Photovoltaic, 2nd edition, ARC Centre for Advanced Silicon Photovoltaic and Photonics, 316p.

Zeghbroeck BV, 2011. Principles of Semiconductor Devices, Third Edition Lausanne $147 \mathrm{p}$. 